\title{
Perancangan Model Pembangkit Listrik dengan Menggunakan Teknologi Pompa Tanpa Motor (Hydraulic Ram Pump)
}

\author{
Jorfri Boike Sinaga ${ }^{1}$, Azhar $^{2}$, Novri Tanti ${ }^{1}$, Sugiman ${ }^{1}$ \\ ${ }^{1}$ Jurusan Teknik Mesin, Fakultas Teknik, Universitas Lampung (UNILA) \\ 2Jurusan Teknik Kimia, Fakultas Teknik, Universitas Lampung (UNILA) \\ Jl. Prof. Dr. Sumantri Brojonegoro No. 1, Bandar Lampung 35145 \\ Telp. (0721)7479221, (0721)701609 ext. 221\&223, Fax: (0721)702767 \\ Email: jorfri6@yahoo.com
}

\begin{abstract}
This paper presents the design of parameters of hydraulic ram pump and hydraulic turbine to use the energy of flowing water for water supply to generate electrical power and irrigation. Design of parameters of hydraulic ram pump with head of water supply of 1,5 $\mathrm{m}$ was obtained: 1,25 in. diameter and $8 \mathrm{~m}$ length of drive pipe, $200 \mathrm{gr}$ and 4,6 cm of weight and diameter of impulse valve, $4.200 \mathrm{~cm}^{3}$ of air chamber volume. The testing results of the hydraulic ram pump model shown that water could be pumped as far as the height of $7 \mathrm{~m}$ and $8 \mathrm{~m}$, with the volume flow rate of 2,755 lit/men and 1,73 lit/men. Design of geometric parameters of cross flow hydraulic turbine with head of water supply of 1,75 $\mathrm{m}$ was obtained: $12 \mathrm{~cm}$ and $8 \mathrm{~cm}$ of external and internal diameter, $25 \mathrm{~cm}$ of runner width, and 18 of runner number. The testing results of the cross flow hydraulic turbine shown that power could be generated 83,47 W with the volume flow rate of 0,01 lit/s and the efficiency of $71,05 \%$ at $799 \mathrm{rpm}$. The testing result also shown that with using volume flow rate of 0,003 lit/s, this turbine could be generated 23,39 $\mathrm{W}$ with the efficiency of 46,64\%. Technically the technology of hydraulic ram pump can be developped and used to supply of water for irrigation and generating of electrical power.
\end{abstract}

Keywords: design, hydraulic ram pump, hydraulic turbine.

\begin{abstract}
Abstrak
Pada makalah ini diberikan perancangan parameter-parameter pompa tanpa motor (hydraulic ram pump) dan turbin air yang akan memanfaatkan energi aliran air untuk membangkitkan energi listrik dan menyuplai air untuk irigasi. Perancangan parameter-parameter pompa tanpa motor dengan menggunakan head sumber air 1,5 m digunakan diameter dan panjang pipa suplai 1,25 in. dan $8 \mathrm{~m}$, berat dan diameter katup buang (impulse valve) $200 \mathrm{gr}$ dan 4,6 cm, dan volume tabung udara $4.200 \mathrm{~cm}^{3}$. Hasil pengujian model pompa tanpa motor menunjukkan model ini mampu memompakan air hingga ke ketinggian $7 \mathrm{~m}$ dan $8 \mathrm{~m}$ dengan laju aliran volume yang dipompakan 2,755 lit/men dan 1,73 lit/men. Perancangan parameter-parameter turbin aliran silang (cross flow) dengan tinggi head air suplai 1,75 m diperoleh: diameter luar dan dalam turbin $12 \mathrm{~cm}$, dan $8 \mathrm{~cm}$, lebar turbin $25 \mathrm{~cm}$, dan jumlah sudu yang digunakan 18 buah. Hasil pengujian menunjukan turbin ini dapat menghasilkan daya 83,47 W dan efisiensi 71,05 \% dengan laju aliran volume 0,01 lit/s pada pengoperasian 799 rpm. Hasil pengujian juga menunjukkan bahwa dengan menggunakan laju aliran volume 0,003 lit/s dihasilkan daya 23,39 W dengan efisiensi 46,64\%. Secara teknik teknologi pompa tanpa motor ini dapat digunakan untuk menyuplai air untuk irigasi dan untuk membangkitkan energi listrik.
\end{abstract}

Keywords: perancangan, pompa tanpa motor, turbin air.

\section{PENDAHULUAN}

Pemanfaatan potensi energi selain sumber energi fosil ini dirasa amat perlu mengingat tingginya kebutuhan listrik, dimana saat ini terjadi defisit energi listrik. Defisit ini terjadi karena tingkat pertumbuhan permintaan tenaga listrik yang cukup tinggi. Dimana dari 4355 desa yang ada di Provinsi Lampung, 685 diantaranya belum masuk aliran listrik [1]. Hal ini diakibatkan keterbatasan dana PLN sebagai penyedia listrik, dan juga akibat pemanfaatan energi terbarukan yang belum maksimal dilakukan seperti energi aliran sungai untuk sistem pembangkit listrik tenaga mikro hidro atau nano hidro.

Turbin air yang umum digunakan untuk sistem pembangkit listrik adalah yang menggunakan sumber energi aliran air yang harus memiliki tinggi jatuh. Sementara banyak potensi energi aliran air yang hanya memiliki tinggi jatuh rendah atau hanya memiliki energi aliran bebas (tidak memiliki tinggi jatuh) yang belum dimanfaatkan, dimana ketinggian air dapat dinaikkan menjadi lebih tinggi dengan menggunakan pompa tanpa motor (hydraulic ram pump) sehingga nantinya dapat digunakan untuk 
menggerakkan turbin suatu sistem pembangkit listrik, disamping juga dapat dimanfaatkan untuk memenuhi kebutuhan air untuk irigasi maupun rumah tangga. Berdasarkan hal tersebut maka pada makalah ini dilakukan penelitian mengenai sistem pembangkit listrik dengan menggunakan pompa tanpa motor (hydraulic ram pump) untuk memanfaatkan energi aliran yang memiliki tinggi jatuh rendah.

\section{Sistem Pompa Tanpa Motor (Hydraulic Ram Pump)}

Pompa hydraulic ram pump adalah suatu peralatan yang unik dimana peralatan ini menggunakan energi dari aliran air yang memiliki ketinggian jatuh rendah sebagai energi suplai untuk memompa sebagian air ke tempat yang jauh lebih tinggi dari head sumber air. Aliran air yang kontiniu mengakibatkan pengeoperasian pompa ini juga kontinu dengan tidak menggunakan sumber energi lain [2]. Dengan demikian penggunaan hydraulic ram pump ini tentunya sangat baik untuk mendukung pengembangan energi terbarukan (renewable energy) yang bebas polusi.

Instalasi dari seluruh komponen sistem pompa tanpa motor (hydraulic ram pump) dapat dilihat pada Gambar 1. Pompa hydraulic ram pump adalah suatu alat yang sederhana secara struktur, dan terdiri atas dua bagian yang bergerak yaitu: katup buang (waste valve), dan katup pengeluaran (delivery valve). Unit ini juga terdiri atas tangki penyimpan udara (air chamber) dan katup udara (air valve) masuk. Pengoperasian pompa hydraulic ram pump adalah intermitent akibat siklus pembukaan dan penutupan katup buang dan pengeluaran. Tangki penyimpan udara dibutuhkan untuk mencegah tekanan yang tinggi akibat penutupan katup buang dan digunakan untuk memompakan air yang mengalir secara intermitent menjadi suatu aliran yang kontinu.

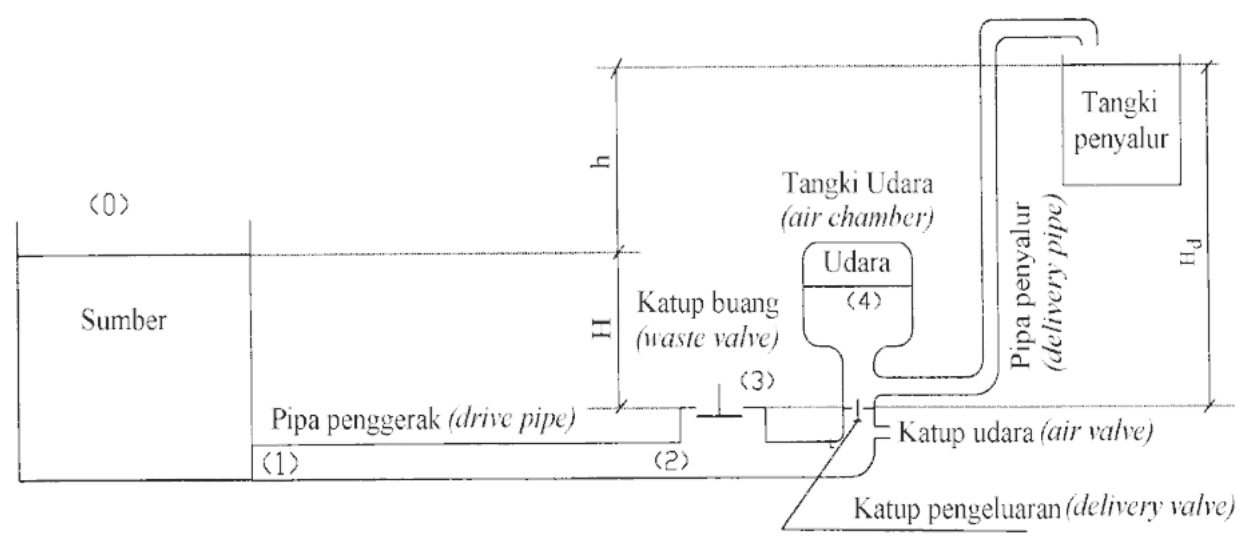

Gambar 1. Instalasi pompa hydraulic ram pump

Ada beberapa parameter yang berhubungan dengan pengeporesain hydraulic ram pump. Parameter-parameter ini adalah [3]: Panjang dan diameter pipa suplai, head sumber, head penyaluran, berat katup, Luas penampang katup dan volume tangki udara

Karena adanya tinggi head $(\mathrm{H})$ sumber seperti pada Gambar 2, maka air di dalam pipa suplai (drive pipe) mengalami percepatan dan keluar melalui katup buang (waste valve). Percepatan ini diberikan oleh Persamaan 1.

$$
\mathrm{H}-\mathrm{f} \frac{\mathrm{L}}{\mathrm{D}} \frac{\mathrm{V}^{2}}{2 \mathrm{~g}}-\sum \mathrm{k} \frac{\mathrm{V}^{2}}{2 \mathrm{~g}}=\frac{\mathrm{L}}{\mathrm{g}} \frac{\mathrm{dV}}{\mathrm{dt}}
$$

$$
\text { Dimana: } \mathrm{H} \text { adalah head sumber (m), } \mathrm{f} \frac{\mathrm{L}}{\mathrm{D}} \frac{\mathrm{V}^{2}}{2 \mathrm{~g}}
$$

adalah kerugian head di dalam pipa akibat gesekan (m), f adalah faktor gesekan (Rumus DarcyWeibach), $\quad \sum \mathrm{k} \frac{\mathrm{V}^{2}}{2 \mathrm{~g}} \square$ adalah jumlah seluruh kerugian head minor (m), $\mathrm{k}$ adalah suatu faktor untk pengcilan atau pembesaran saluran, $\mathrm{L}$ adalah panjang pipa suplai (m), D adalah diameter pipa suplai (m), V adalah kecepatan aliran di dalam pipa (m/det), dan t adalah waktu (det).

Nilai-nilai untuk k dan $\mathrm{f}$ dapat diketahui dari buku mekanika fluida [4]. Akhirnya aliran ini akan memiliki kecepatan yang cukup untuk memulai menutup katup buang (waste valve). Hal ini terjadi bila gaya geseran dan tekanan di dalam air sama dengan berat katup pembuangan. Gaya geseran dihitung dengan menggunakan persamaan di bawah ini

$$
\mathrm{F}_{\mathrm{d}}=\frac{1}{2} \mathrm{C}_{\mathrm{d}} \times \mathrm{Av} \times \rho \times \mathrm{V}^{2}
$$

Dimana: $F_{d}$ adalah gaya geseran yang terjadi pada katup pembuangan $(\mathrm{N}), \mathrm{A}_{\mathrm{V}}$ adalah luas penampang katup pembuangan $\left(\mathrm{m}^{2}\right), \rho$ adalah massa jenis air $=1000 \mathrm{~kg} / \mathrm{m}^{3}, \mathrm{C}_{\mathrm{d}}$ adalah koefisien geseran katup pembuangan. Koefisien geseran $C_{d}$ 
tergantung pada bilangan Reynolds aliran dan bentuk objek. Untuk benda sirkular, $\mathrm{C}_{\mathrm{d}}=1.12$.

\section{Turbin Air}

Turbin adalah alat yang merubah energi aliran air menjadi energi mekanik poros. Pemilihan jenis turbin yang sesuai untuk suatu pembangkit listrik sistem PLTMH atau PLNH tergantung pada karakteristik aliran, yaitu tinggi jatuh dan debit aliran yang tersedia serta kecepatan putaran generataor. Berdasarkan tinggi jatuh (head) air maka turbin dapat diklasifikasikan menjadi head tinggi, head sedang, dan head rendah. Turbin juga dapat diklasifikasikan berdasarkan prinsip pengoperasiannya yaitu turbin impuls dan turbin

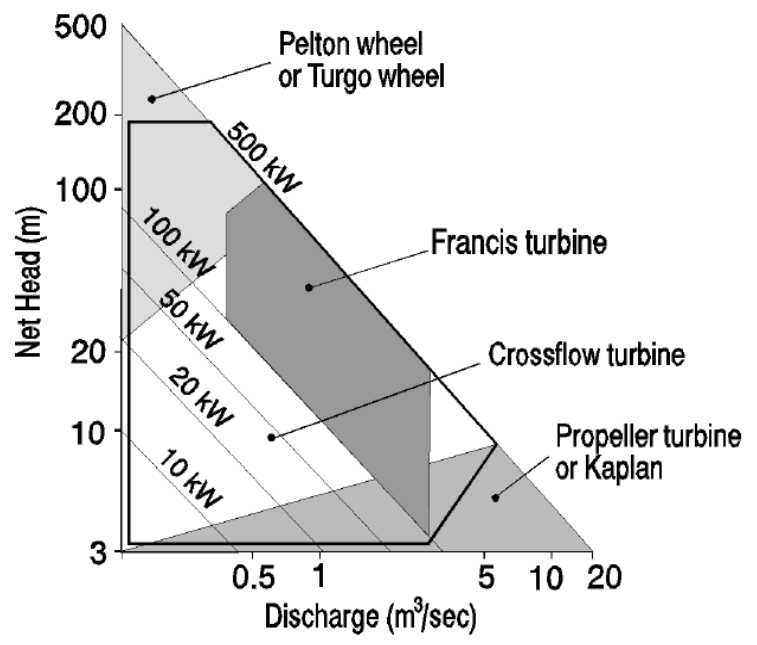

Gambar 2. Daerah pengoperasian untuk berbagai jenis turbin berdasarkan head dan debit aliran [5].

\section{METODE PENELITIAN}

\section{Perancangan Alat Uji}

Untuk mengetahui pengaruh parameterparameter perancangan hydraulic ram pump seperti: panjang dan diameter pipa suplai, berat dan luas penampang katup buang $\mathrm{W}$ dan A terhadap debit air dan tinggi air yang dipompakan dan parameter-parameter perancangan turbin seperti: diameter, panjang, dan jumlah sudu terhadap unjuk kerja turbin seperti: torsi yang dihasilkan turbin $\mathrm{T}$, daya poros turbin $\mathrm{P}_{\mathrm{t}}$, dan efisiensi turbin $\eta_{\mathrm{t}}$. Penentuan parameter-parameter hydraulic ram pump sesuai dengan potensi tinggi jatuh aliran sumber $\mathrm{H}$, dan tinggi $\mathrm{h}$ dan laju aliran volume pemompaan Qp. Model sistem pembangkit listrik menggunakan hydraulic ram pump yang akan dirancang dapat dilihat seperti pada Gambar 3. Pembuatan alat pengujian model sistem pembangkit listrik ini dilakukan di Laboratorium Mekanika Fluida Jurusan Teknik Mesin, Universitas reaksi.

Gambar 2 memberikan penentuan pemilihan jenis turbin yang akan digunakan pada suatu pembangkit listrik berdasarkan data-data head bersih turbin $\mathrm{H}_{\mathrm{T}}(\mathrm{m})$ dan debit aliran $\mathrm{Q}\left(\mathrm{m}^{3} / \mathrm{s}\right)$ sumber aliran yang akan digunakan. Daya yang dihasilkan turbin dihitung dengan menggunakan persamaan di bawah ini:

$$
\mathrm{P}_{\mathrm{t}}=\gamma \mathrm{QH}_{\mathrm{t}} \eta_{\mathrm{t}}
$$

dimana $\mathrm{P}_{\mathrm{t}}$ adalah daya yang dihasilkan turbin $(\mathrm{kW})$, $\gamma$ adalah berat jenis air $\left(9,18 \mathrm{kN} / \mathrm{m}^{3}\right), \mathrm{Q}$ adalah kapasitas aliran $\left(\mathrm{m}^{3} / \mathrm{s}\right)$, Ht adalah tinggi jatuh (head) bersih (m), dan $\eta_{\mathrm{t}}$ adalah efisiensi turbin. 
Unjuk kerja turbin diperoleh dengan mengetahui daya air $\mathrm{P}_{h}$, daya poros turbin $\mathrm{P}_{t}$, dan efisiensi turbin $\eta_{t}$. Besar daya air ini dapat dihitung dengan menggunakan persamaan

$$
\mathrm{P}_{\mathrm{h}}=\rho \mathrm{g} \mathrm{Q} \mathrm{H}_{\mathrm{t}}
$$

dimana $\rho$ adalah massa jenis air $\left(1.000 \mathrm{~kg} / \mathrm{m}^{3}\right)$, dan Ht tinggi head turbin (m). Daya yang dihasilkan poros turbin dapat dihitung dengan menggunakan persamaan:

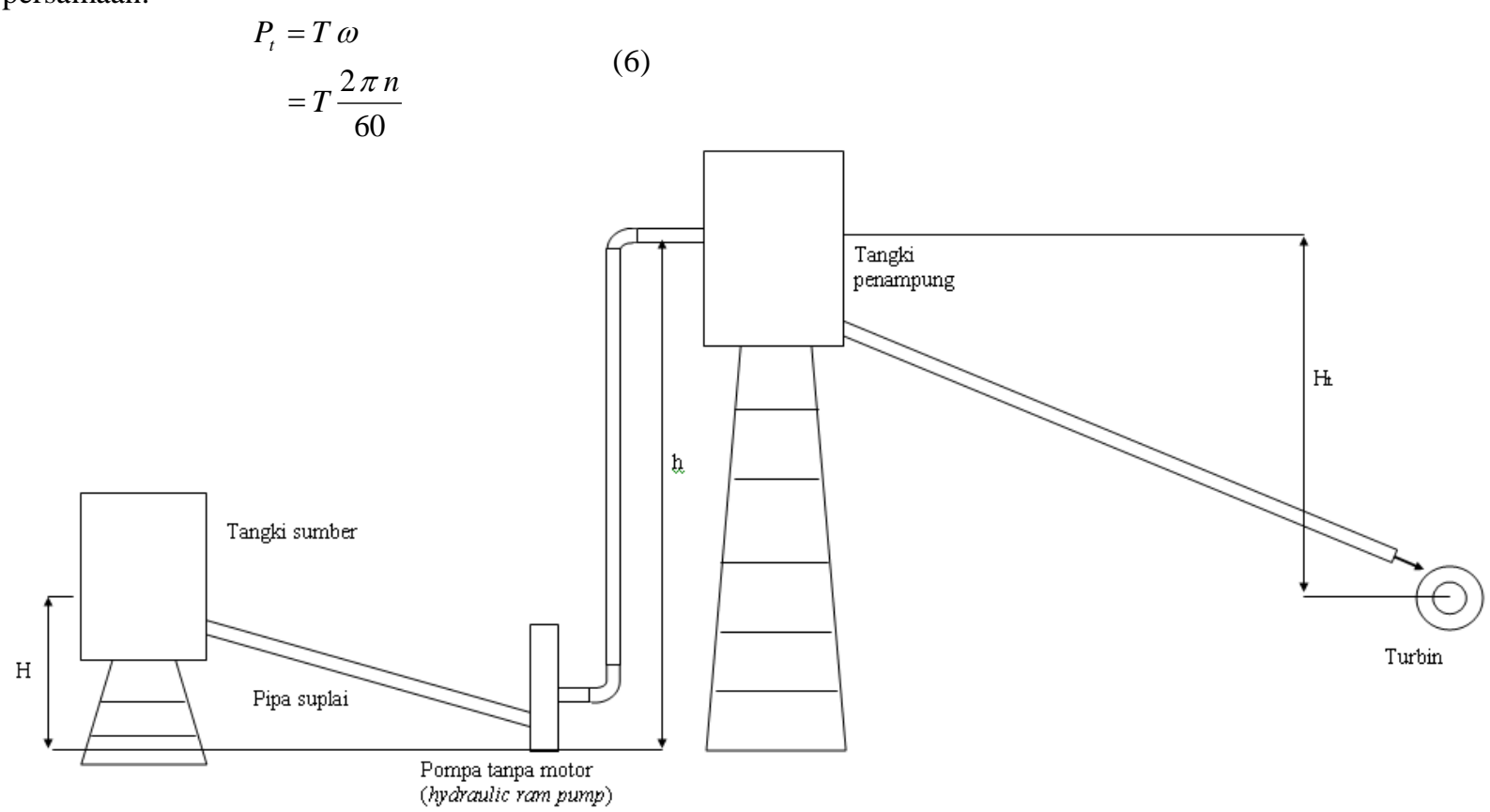

dimana T (N.m) adalah torsi yang didapat dari pengukuran langsung menggunakan torsi meter, dan $\mathrm{n}$ adalah putaran turbin (rpm) diperoleh dari pengukuruan menggunakan tachometer. Dan efisiensi turbin $\eta_{\mathrm{t}}$ dapat dihitung dengan

$$
\eta_{\mathrm{t}}=\frac{\mathrm{P}_{\mathrm{t}}}{\mathrm{P}_{\mathrm{h}}}
$$
menggunakan persamaan:

Gambar 3. Skema model pengujian sistem pemabangkit listrik menggunakan hydraulic ram pump yang akan diuji di Laboratorium Mekanika Fluida, Jurusan Teknik Mesin, Universitas Lampung.

\section{HASIL DAN PEMBAHASAN}

\section{Rancangan Model Pompa Tanpa Motor (Hydram Pump)}

Model hydram pump ini dirancang untuk ketinggian head sumber $1,5 \mathrm{~m}$. Parameterparameter perancangan model hydram pump yang digunakan dapat dilihat pada Tabel 1 [6;7]. Hasil rancangan model hydram pump dapat dilihat pada Gambar 4
Tabel 1. Parameter-parameter model pompa tanpa motor (hydram pump).

\begin{tabular}{|ccc|}
\hline Tinggi Head sumber & $:$ & $1,5 \mathrm{~m}$ \\
\hline Volume Tabung udara & $:$ & $4.771 \mathrm{~cm}^{3}$ \\
\hline Diameter pipa suplai & $:$ & $11 / 4 \mathrm{in}$. \\
\hline Panjang pipa suplai & $:$ & $4,7 \mathrm{~m}$ \\
\hline Diameter pipa penyalur & $:$ & $5 / 8 \mathrm{in}$. \\
\hline Diameter katup buang & $:$ & $4,6 \mathrm{~cm}$ \\
\hline Berat katup buang & $:$ & $0,2 \mathrm{~kg}$ \\
\hline Setelah dilakukan pembuatan model
\end{tabular}
hydraulic ram pump, maka dilakukan pengujian untuk mengetahui unjuk kerja hydraulic ram pump tersebut. Tinggi sumber air yang digunakan yaitu 1,5 $\mathrm{m}$ dan ketinggian pemompaan divariasikan dari tinggi $7 \mathrm{~m}$, dan $8 \mathrm{~m}$. Hasil pengujian model hydraulic ram pump ini dapat dilihat pada Gambar 5 sampai dengan Gambar 8. 


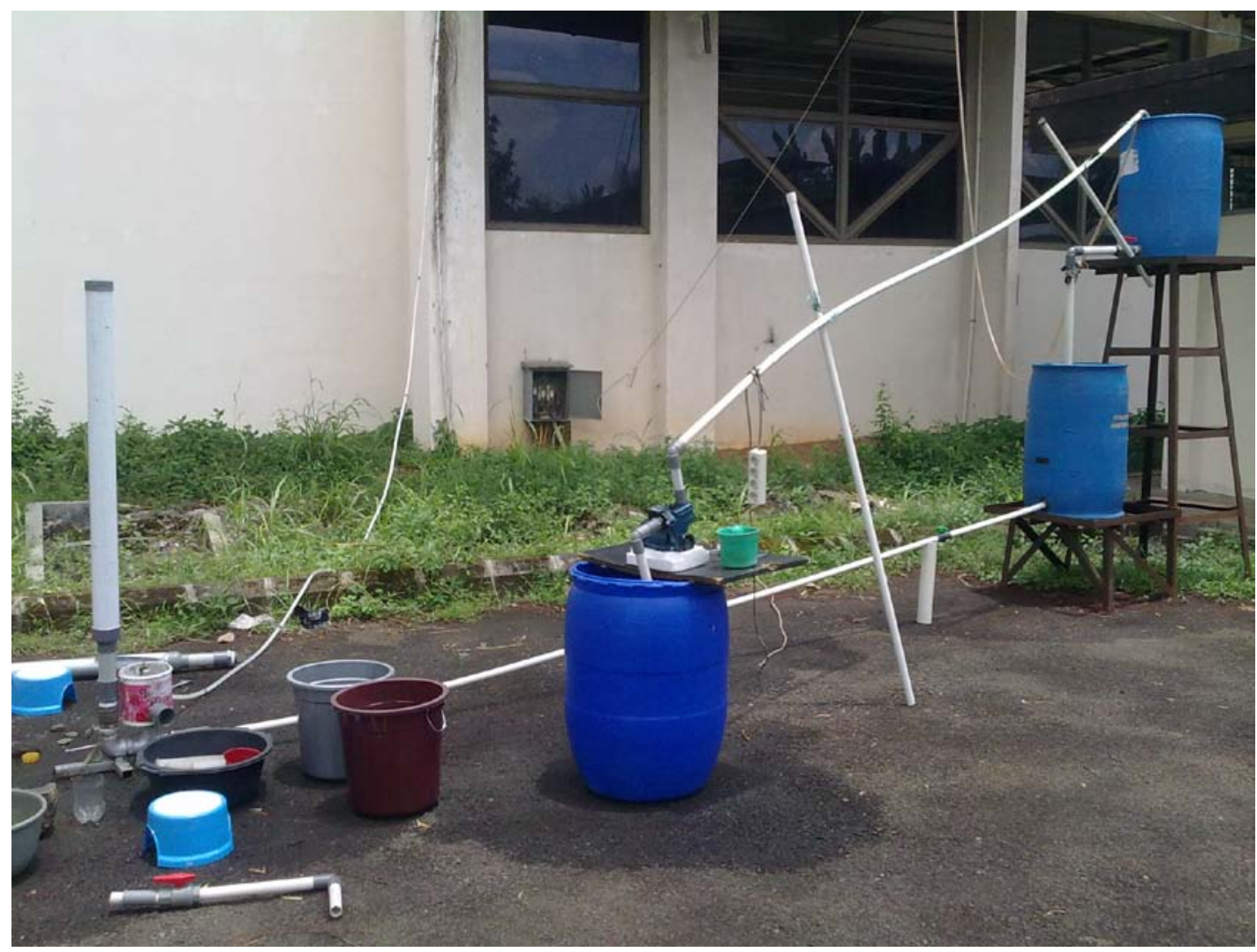

Gambar 4. Model pompa tanpa motor (hydram pump) yang dirancang.

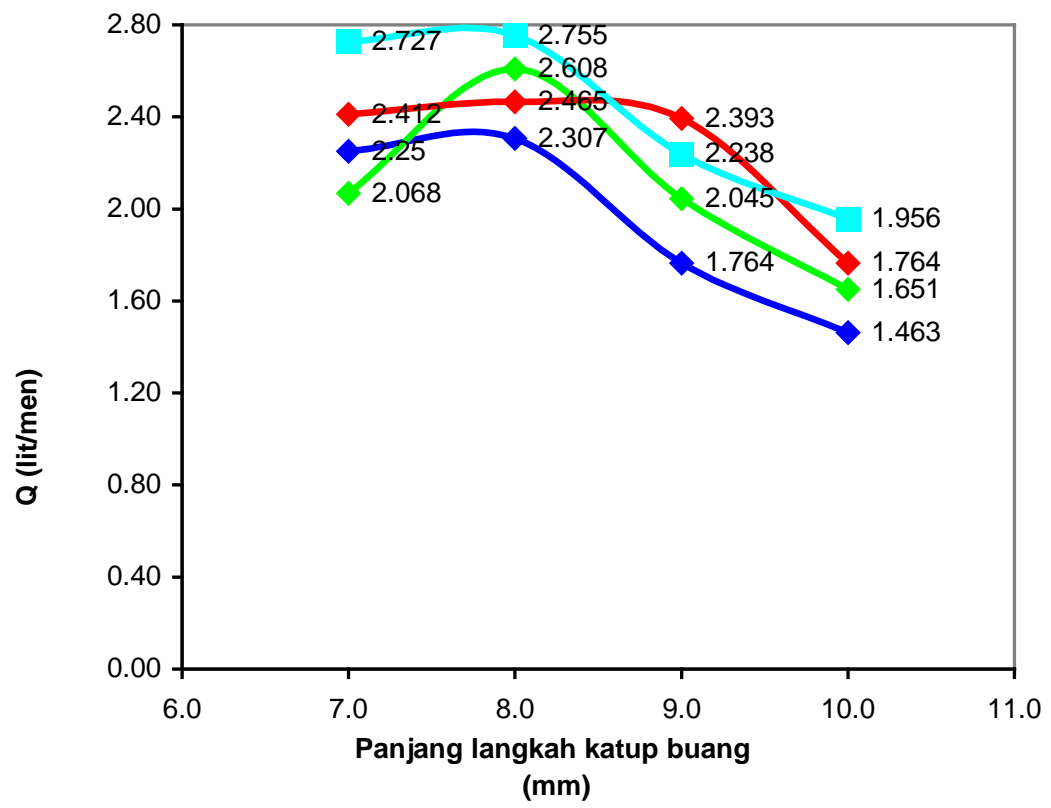

$\neg-\mathrm{m}=120 \mathrm{gr} \rightleftharpoons \mathrm{m}=147 \mathrm{gr} \leadsto-\mathrm{m}=174 \mathrm{gr}=-\mathrm{m}=201 \mathrm{gr}$

Gambar 5. Grafik hubungan antara laju aliran volume air yang disalurkan terhadap panjang langkah katup buang untuk tinggi head pemompan $7 \mathrm{~m}$ 


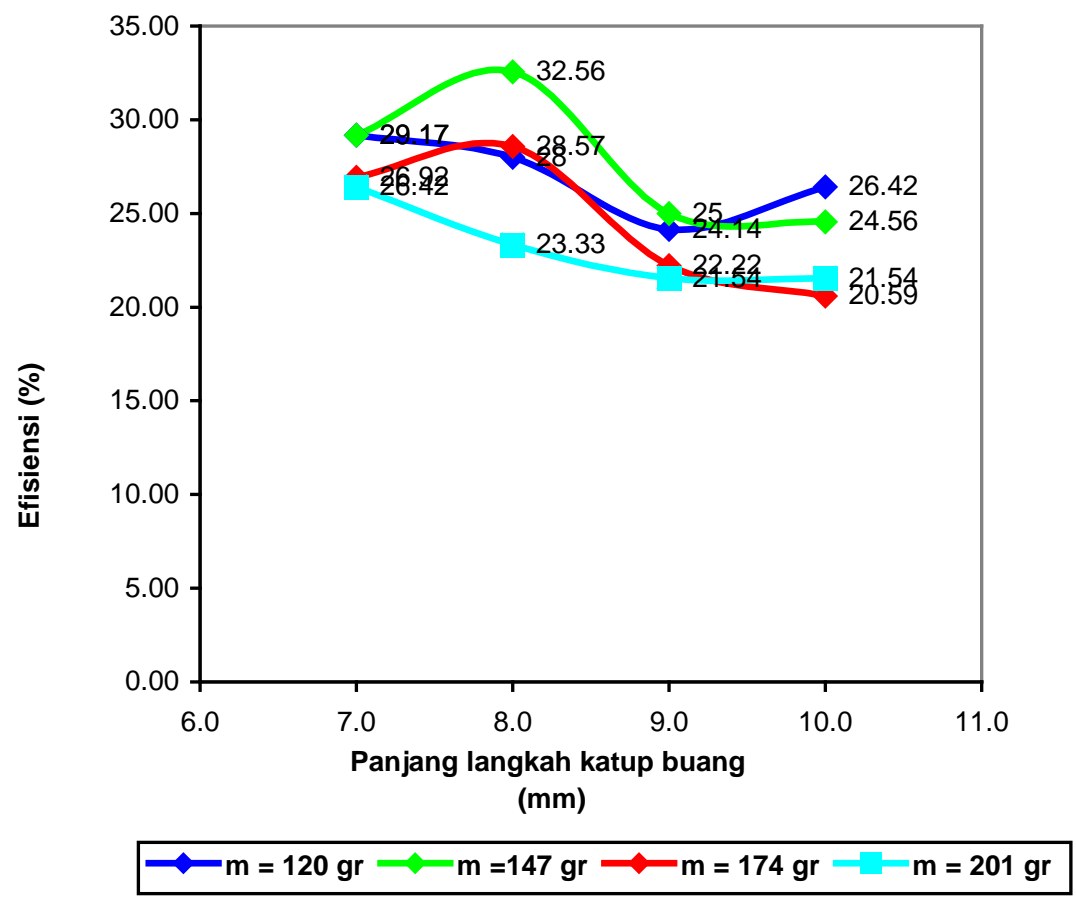

Gambar 6. Grafik hubungan antara efisiensi terhadap panjang langkah katup buang untuk tinggi head pemompan $7 \mathrm{~m}$

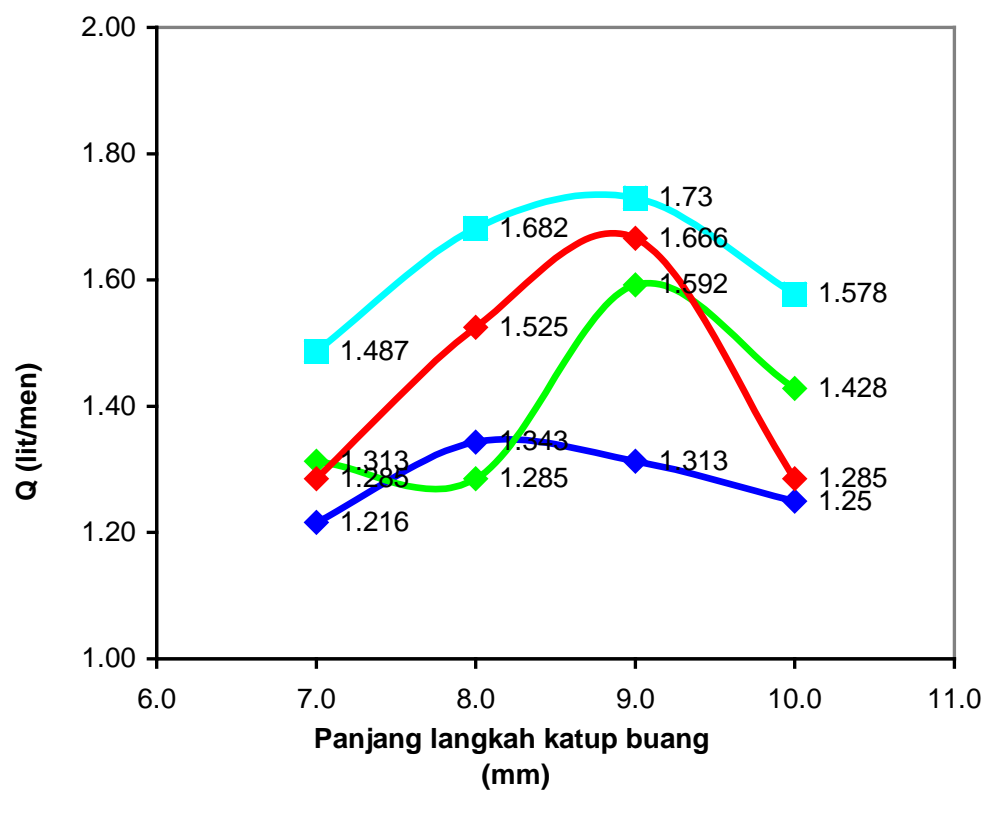

$\neg-\mathrm{m}=120 \mathrm{gr} \asymp \mathrm{m}=147 \mathrm{gr} \leadsto \mathrm{m}=174 \mathrm{gr} \longleftarrow-\mathrm{m}=201 \mathrm{gr}$

Gambar 7. Grafik hubungan antara laju aliran volume air yang disalurkan terhadap panjang langkah katup buang untuk tinggi head pemompan $8 \mathrm{~m}$ 


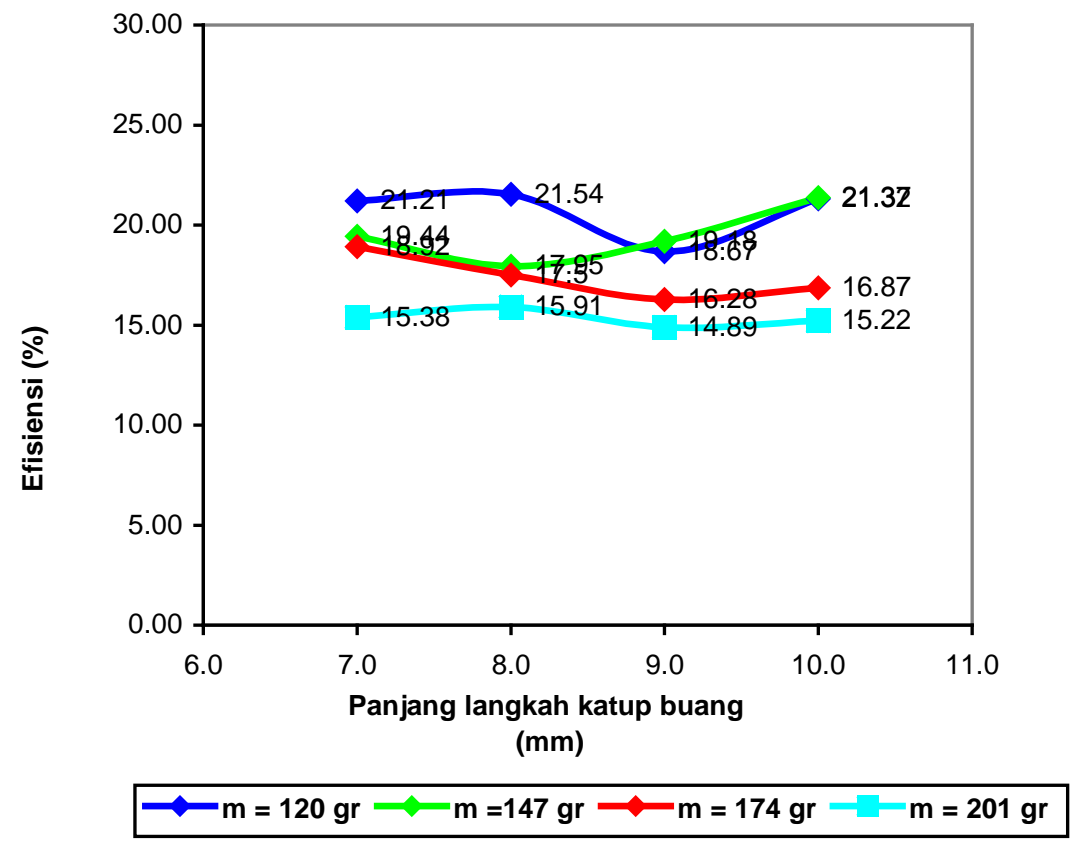

Gambar 8. Grafik hubungan antara efisiensi terhadap panjang langkah katup buang untuk tinggi head pemompan $8 \mathrm{~m}$

Dari hasil pengujian dapat dilihat bahwa berat katup buang mempengaruhi debit pemompaaan maksimum, untuk ketinggian $7 \mathrm{~m}$, dan $8 \mathrm{~m}$ adalah dengan menggunakan berat katup buang 201 gr dengan debit pemompaan maksimum yaitu 2,755 lit./menit, dan 1,730 lit./menit. Namun pengoperasian dengan menggunakan berat katup buang 201 gr ini tidak memberikan pengoperasian dengan efisiensi maksimum bila dibandingkan dengan menggunakan berat katup buang 120 gr, 147 gr, dan 174 gr, tetapi yang diinginkan dari pengoperasian pompa tanpa motor ini adalah debit aliran maksimum yang dipompakan, karena energi penggerak air ini adalah energi aliran air itu sendiri. Hasil pengujian menunjukkan bahwa bila digunakan pompa 4 atau 5 buah, maka aliran yang dipompakan akan memiliki potensi untuk massa katup buang ini mendekati massa katup buang yang dihitung dengan menggunakan pemodelan aliran di dalam pompa.

\section{Rancangan Model Sistem Pembangkit Listrik}

Model sistem pembangkit listrik yang dirancang menggunakan turbin air aliran silang (cross flow), dimana penggunaan turbin ini sesuai dengan potensi sumber energi air yang memiliki tinggi jatuh rendah dan turbin ini memiliki unjuk kerja yang tetap konstan dibanding dengan turbin lainnya walaupun debit aliran berkurang sampai 30 $\%$ dari debit aliran perancangan [8]. Head sumber yang digunakan untuk model sistem pembangkit ini adalah 1,75 m. Model sistem pembangkit listrik yang dibangun dapat dilihat pada Gambar 9. Diameter pipa pesat yang digunakan adalah 2,5 in. [9].

Model turbin aliran silang (cross flow) dan roda gila (fly wheel) yang digunakan pada sistem pembangkit listrik dapat dilihat pada Gambar 18. Parameter-parameter perancangan model turbin aliran silang yang digunakan dapat dilihat pada Tabel 2 [10].

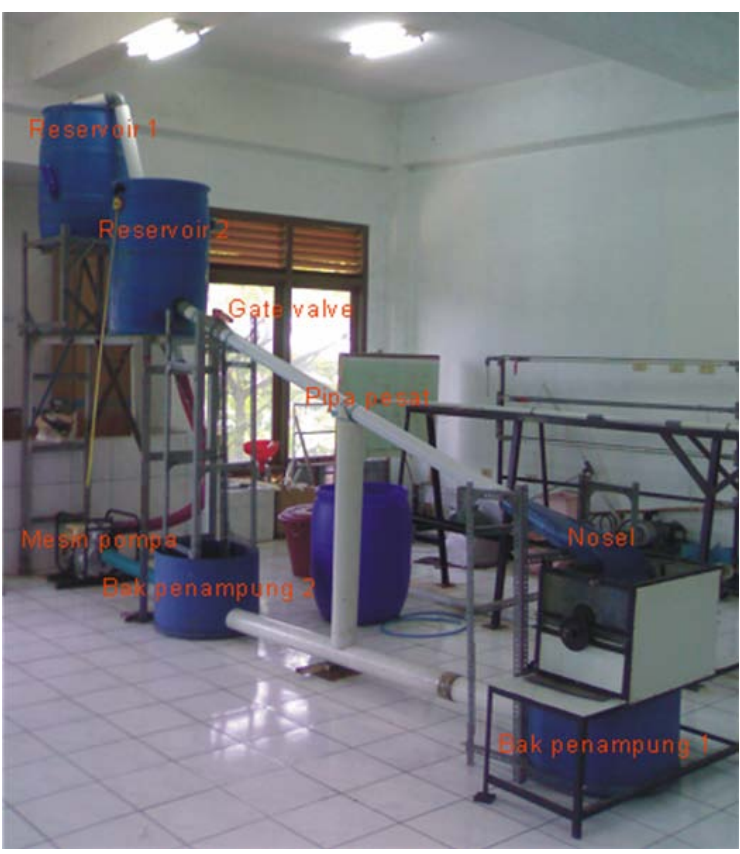

Gambar 9. Model sistem pembangkit listrik yang dirancang. 


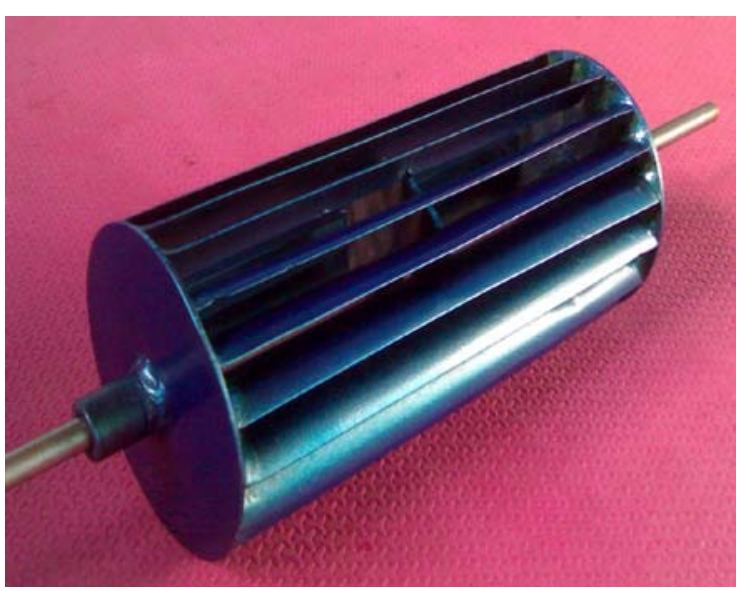

Gambar 10. Model turbin aliran silang (cross flow)

Tabel 2 Hasil perancangan parameter turbin air

\begin{tabular}{|l|l|}
\hline Putaran turbin $(\mathrm{N})$ & $368 \mathrm{rpm}$ \\
\hline Kecepatan aliran masuk $\left(\mathrm{V}_{1}\right)$ & $4,75 \mathrm{~m} / \mathrm{s}$ \\
\hline Putaran turbin $(\mathrm{N})$ & $338 \mathrm{rpm}$ \\
\hline Kecepatan keliling aliran masuk $\left(\mathrm{U}_{1}\right)$ & $2,28 \mathrm{~m} / \mathrm{s}$ \\
\hline Diameter luar turbin $\left(\mathrm{D}_{1}\right)$ & $0,12 \mathrm{~m}$ \\
\hline Diameter dalam turbin $\left(\mathrm{D}_{2}\right)$ & $0,08 \mathrm{~m}$ \\
\hline Panjang turbine $(\mathrm{L})$ & $0,25 \mathrm{~m}$ \\
\hline Jari-jari kelengkungan sudu $(\rho)$ & $0,019 \mathrm{~m}$ \\
\hline Jarak antara sudu $(\mathrm{t})$ & $0,02 \mathrm{~m}$ \\
\hline Jumlah sudu turbine $(\mathrm{z})$ & 18 \\
\hline Ketebalan semburan air $(\mathrm{So})$ & $0,018 \mathrm{~m}$ \\
\hline & \\
\hline
\end{tabular}

Hasil pengujian model sistem pembangkit listrik ini dapat dilihat pada Gambar 11 dan Gambar 12. Dari hasil pegujian model turbin crossflow diperoleh efisiensi maksimum sebesar 71,05 \% dengan daya yang dihasilkan turbin 83,47 W dengan menggunakan head $1,75 \mathrm{~m}$. Turbin ini beroperasi pada 702 rpm dengan menggunakan berat flywheel $1,2 \mathrm{~kg}$, dengan debit aliran turbin $0,01 \mathrm{~m}^{3} / \mathrm{s}$. Disamping itu turbin ini juga masih dapat beroperasi dimana debit aliran turun hingga $0,003 \mathrm{~m}^{3} / \mathrm{s}$ dengan efisiensi pengoperasian 36,64\% dengan daya yang dihasilkan 18,32 $\mathrm{W}$, pada putaran 472 rpm. Jadi air yang dipompakan mengunakan pompa tanpa motor dapat digunakan untuk menggerakkan turbin model sistem pembangkit listrik ini, dimana air yang dipompakan telah memiliki head ketinggian yang jauh lebih tinggi dari head sumber dimana model pompa tanpa motor yang dirancang ini mampu memompakan sampai ke ketinggian $7 \mathrm{~m}$, dan $8 \mathrm{~m}$.

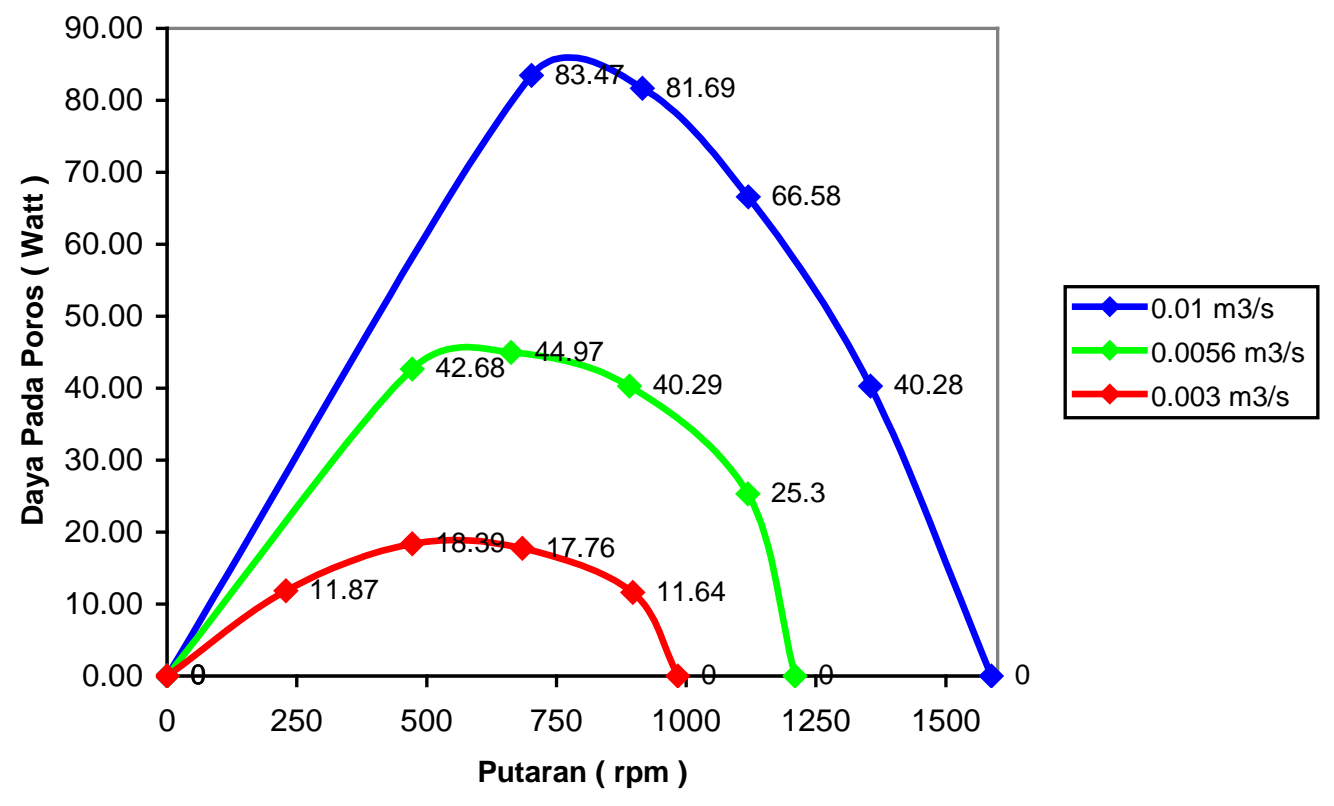

Gambar 11. Grafik hubungan antara daya poros terhadap putaran turbin turbin untuk berat roda gila 1,2 kg. 


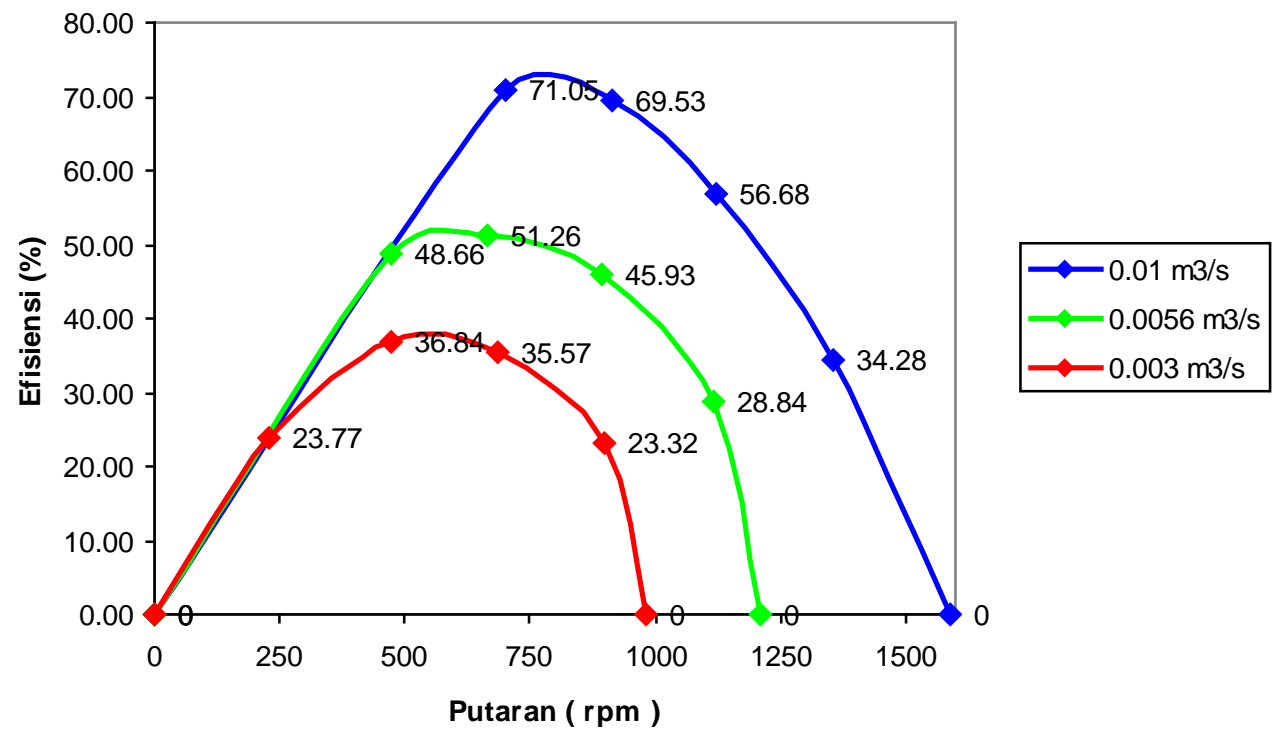

Gambar 12. Grafik hubungan antara efisiensi terhadap putaran turbin untuk berat roda gila $1,2 \mathrm{~kg}$. untuk menyuplai air untuk irigasi dan untuk membangkitkan energi listrik.

\section{DAFTAR PUSTAKA}

\section{KESIMPULAN}

Pada penelitian ini diberikan metode perancangan parameter-parameter pompa tanpa motor (hydraulic ram pump) dan parameterparameter turbin yang digunakan untuk sistem pembangkit listrik dan irigasi yang digunakan untuk memanfaatkan energi aliran yang memiliki tinggi jatuh sangat rendah atau hanya energi aliran saja. Perancangan model hydraulic ram pump dengan head sumber $1,5 \mathrm{~m}$ digunakan diameter pipa suplai 1,25 in., panjang pipa suplai $8 \mathrm{~m}$, berat dan diameter katup buang 200 gr dan 4,6 cm, dan volume tabung udara $7.469 \mathrm{~cm}^{3}$. Hasil pengujian menunjukkan dengan head sumber $1,5 \mathrm{~m}$ pompa hydraulic ram ini mampu memompakan air sampai ketinggian $8 \mathrm{~m}$, dengan debit aliran yang dipompakan 1,67 lit./men.,

Perancangan model turbin aliran silang (cross flow) digunakan parameter-parameter: diameter luar $12 \mathrm{~cm}$, diameter dalam $8 \mathrm{~cm}$, panjang turbin 25 $\mathrm{cm}$, dan jumlah sudu 18 buah. Hasil pengujian model sistem pembangkit dengan menggunakan tinggi jatuh $1,75 \mathrm{~m}$, dan debit aliran $0,01 \mathrm{~m}^{3} / \mathrm{s}$ daya yang dihasilkan turbin mencapai 83,47 W dan efisiensi turbin 71,05 \% pada pengoperasin 702 rpm. Namun turbin juga dapat bekerja dengan debit aliran turun sampai $0,003 \mathrm{~m}^{3} / \mathrm{s}$ dimana daya yang dihasilkan turbin mencapai 18,32 W dan efisiensi pengoperasian turbin 36,64 \%. Secara teknik teknologi pompa tanpa motor ini dapat digunakan
[1] -----.(2014). Masih Ada Desa di Lampung Belum Dialiri Listrik, Diakses tanggal 22 April 2016 dari http://nasional.republika.co.id/ berita/nasional/daerah/13/02/18/mif70b-masihada-desa-di-lampung-belum-dialiri-listrik

[2] Taye, T. 1999., Hydraulic Ram Pump, Journal of the Ethiopian Society of Mechanical Engineers, Vol. II, No. L.

[3] Tessema, A. A., 2000. Hydraulic Ram Pump System Design And Application. ESME 5th Annual Conference on Manufacturing and Process Industry, held at Addis Ababa, Ethiopia , September 2000.

[4] Fox, R. W., and Mc Donald, A. T., 1995. Introduction to Fluid Mechanics. John Wiley \& Sons, New York.

[5] DTI., 2004. HydroPak concept design and analysis of a packaged cross-flowturbine. Final report Contract Number: H/03/00078/00/00, NHT Engineering and IT Power Ltd.

[6] Sinaga, J. B., Azhar, dan Sugiman, 2016a. Perancangan Alat Uji Model Pompa Tanpa Motor (Hydraulic Ram Pump), Prosiding Seminar Nasional Sains dan Teknologi, Fakultas Teknik, Universitas Muhamadiyah, Jakarta.

[7] Sinaga, J. B., Azhar, dan Sugiman, 2016 b. Pemodelan Aliran Pada Pipa Suplai Untuk Menentukan Berat Katup Buang (Waste Valve) Pompa Tanpa Motor (Hydraulic Ram Pump), 
Prosiding Seminar Nasional SMIAP IV, Fakultas Matematika dan Ilmu Pengetahuan Alam, Universitas lampung, Bandar Lampung.

[8] Kaldellis, J.K., Vlachou, D.S. and G. Korbakis. 2005. Techno-economic evaluation of small hydro power plants in Greece: a complete sensitivity analysis. Energy Policy 33: 19691985.

[9] Sinaga, J. B., Azhar, N. Tanti, dan Sugiman, 2015a. Pemodelan Aliran di Dalam Pipa untuk Menentukan Diameter Pipa Pesat Sistem PLTMH, Prosiding Seminar Nasional Hasilhasil Penelitian dan Pengabdian Kepada Masyarakat Universitas Lampung, Bandar Lampung.

[10] Sinaga, J. B., Azhar, dan N. Tanti, 2015b. Rancang Bangun Model Pembangkit Listrik dengan Menggunakan Teknologi Pompa Tanpa Motor (Hydraulic Ram Pump) untuk Membantu Memenuhi Listrik Pedesaan di Provinsi Lampung. Laporan Tahun Pertama Hibah Bersaing, Universitas lampung, Bandar Lampung. 